The University of Maine

\title{
DigitalCommons@UMaine
}

Maine-Syracuse Longitudinal Papers

Maine-Syracuse Longitudinal Study

2017

\section{The Renaissance of Heart Rate Variability as a Predictor of Cognitive Functioning}

Merrill F. Elias

University of Maine, mfelias@maine.edu

Rachael V. Torres

Follow this and additional works at: https://digitalcommons.library.umaine.edu/

longitudinal_papers

\section{Repository Citation}

Elias, Merrill F. and Torres, Rachael V., "The Renaissance of Heart Rate Variability as a Predictor of Cognitive Functioning" (2017). Maine-Syracuse Longitudinal Papers. 70.

https://digitalcommons.library.umaine.edu/longitudinal_papers/70

This Article is brought to you for free and open access by DigitalCommons@UMaine. It has been accepted for inclusion in Maine-Syracuse Longitudinal Papers by an authorized administrator of DigitalCommons@UMaine. For more information, please contact um.library.technical.services@maine.edu. 
AQ1

1.5

\author{
Merrill F. Elias ${ }^{1}$ and Rachael V. Torres $^{2}$
}

\section{The Renaissance of Heart Rate Variability as a Predictor of Cognitive Functioning}

Heart rate variability (HRV) is defined as variation in the time interval between heartbeats. It is determined by interactions between the sympathetic and parasympathetic branches of the autonomic nervous system. Low HRV is an indicator of autonomic dysfunction and is associated with cardiovascular (CVD) risk factors and events that are also related to lower levels of performance on cognitive tests. ${ }^{1}$ Poor cognitive performance associated with reduced HRV may thus be a consequence of HRV-associated risk factors or, more directly, the failure of the autonomic nervous system to properly regulate brain perfusion. The article by Zeki Al Hazzouri et al. ${ }^{2}$ in this issue of the American Journal of Hypertension signifies the rebirth of interest in relations between HRV and cognition.

There were an estimated 261 published articles on blood pressure and cognitive functioning in $2011,{ }^{1}$ but few on HRV. Table 1 identifies the major studies cited by Zeki Al Hazzouri et al. ${ }^{2-8}$ including possibly the earliest well-controlled study by Kim et al. ${ }^{3}$ in 2006. A review by Richard and Casey traces the study of HRV back to $1973^{9}$ where HRV was employed as an index of attention. In these early studies, both variables were often measured concurrently and HRV was found to index orientation and attention in infants, children, and adults. More recently, Mukherjee et al. ${ }^{10}$ found that HRV was associated with different levels of mental workload. More importantly, Luft et al. ${ }^{11}$ found difference in HRV during performance of executive functioning (EF) vs. non-EF tasks. These studies are pertinent to the design of current studies in this area of research because they indicate need for temporal separation between measurements. The 5-year prospective design of the study by Zeki Al Hazzouri et al. is thus a major strength. Additional strengths are the large sample, control for CVD risk factors associated with HRV, and exclusion of persons with arrhythmias.

Zeki Al Hazzouri et al. utilized data from 2,118 participants of the Coronary Artery Risk Development in Young Adults study that had no electrocardiogram-based evidence of arrhythmias (mean age 45.3 years; $57.7 \%$ female; $43 \%$ African American). HRV measures were created from a 10-second, 12-lead electrocardiogram conducted in 2005 and were used to predict cognitive function, which was assessed in 2010. Two HRV measures included the SD of normal-to-normal intervals (SDNN) and the root mean square of successive differences (RMSSD). Cognitive tests utilized were the Rey Auditory Verbal Learning Test (indexing verbal memory), the Digit Symbol Substitution Test (indexing processing speed), and the Stroop Interference Test (indexing EF). The RMSSD index of HRV was not associated with any cognitive outcomes, although quartile of SDNN was related to performance on the Stroop Test with adjustment for demographics and CVD risk factors (i.e., smoking status, physical activity, body mass index, blood pressure, antihypertensive medication use, diabetes, history of stroke or myocardial infarction, and depressed mood). In these analyses, participants in SDNN quartiles 2 (range 17.4-26.6 ms) and 3 (26.6-40.7 ms) performed significantly better than those in quartile 1 (range 2.7-17.4 ms). Zeki Al Hazzouri et al. conclude that low HRV is associated with reduced EF. The broad definition of EF is set of processes that have to do with managing oneself and one's resources in order to achieve a goal. They rely heavily on fluid intellectual ability and involve working memory, mental flexibility, and inhibition of incorrect responses as task demands shift. Thus, we prefer a narrower interpretation of the specific construct measured by the Stoop Interference Test because it more specifically measures ability to sustain attention and respond appropriately to shifting task demands.

Low HRV was also significantly associated with lower Digit Symbol Substitution Test score, reflecting mainly speed and to a lesser extent memory. However, this was only true for analyses adjusting for demographics. Absence of findings with adjustment for CVD risk factors may indicate that CVD risk factors may be important mediators of relations between processing speed and cognition. No significant associations

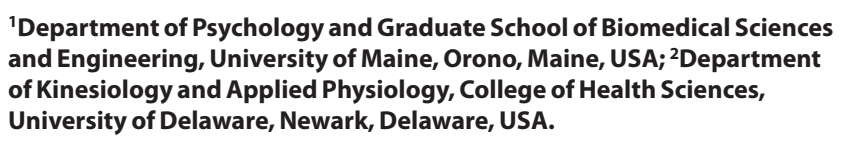

'Department of Psychology and Graduate School of Biomedical Sciences and Engineering, University of Maine, Orono, Maine, USA; ${ }^{2}$ Department of Kinesiology and Applied Physiology, College of Health Sciences, University of Delaware, Newark, Delaware, USA.

doi:10.1093/ajh/hpx150

๑) American Journal of Hypertension, Ltd 2017. All rights reserved. For Permissions, please email: journals.permissions@oup.com 
Commentary

Table 1. Summary of major studies cited by Zeki Al Hazzouri et al. relating HRV to cognitive performance

\begin{tabular}{|c|c|c|c|c|c|}
\hline Study & Design(s) & Participants & HR measurement & Cognitive measures & $\begin{array}{l}\text { Findings with adjustment } \\
\text { for CV-RFs }\end{array}$ \\
\hline $\begin{array}{l}\text { Kim et al. } \\
2006^{3}\end{array}$ & Cross-sectional & $\begin{array}{l}311 \text { physically } \\
\text { disabled females } \\
(\geq 65 \text { years of age) }\end{array}$ & $\begin{array}{l}\text { 2-hour ambulatory } \\
\text { ECG }\end{array}$ & $\begin{array}{l}\text { The Mini-Mental State } \\
\text { Examination (MMSE) }\end{array}$ & $\begin{array}{l}\text { Reduced HRV was associated } \\
\text { with cognitive impairment on } \\
\text { the MMSE (score <24) }\end{array}$ \\
\hline $\begin{array}{l}\text { Britton et al., } \\
2008^{4}\end{array}$ & $\begin{array}{l}\text { Cross-sectional } \\
\text { longitudinal } \\
\text { prospective }\end{array}$ & $\begin{array}{l}5375 \text { males } \\
(55 \pm 6 \text { years of } \\
\text { age) and females } \\
(61 \pm 6 \text { years of age })\end{array}$ & $\begin{array}{l}\text { 5-minute supine } \\
\text { resting ECG }\end{array}$ & $\begin{array}{l}20 \text {-word free recall test, } \\
1 \text {-minute free recall of ' } S \text { ' } \\
\text { words, } 1 \text {-minute free recall } \\
\text { of animal names, the } \\
\text { Alice-Heim } 4-\text { - and the Mill } \\
\text { Hill Vocabulary Test }\end{array}$ & $\begin{array}{l}\text { No consistent cross-sectional, } \\
\text { prospective or longitudinal } \\
\text { associations between HRV } \\
\text { and cognitive performance } \\
\text { were found }\end{array}$ \\
\hline $\begin{array}{l}\text { Shah et al., } \\
2011^{5}\end{array}$ & Cross-sectional & $\begin{array}{l}416 \text { male twins } \\
(55 \pm 2.9 \text { years of } \\
\text { age })\end{array}$ & $\begin{array}{l}\text { 24-hour ambulatory } \\
\text { ECG }\end{array}$ & $\begin{array}{l}\text { Visual and Verbal Selective } \\
\text { Reminding Tests (SRT) }\end{array}$ & $\begin{array}{l}\text { Increased HRV was } \\
\text { associated with higher verbal } \\
\text { SRT score }\end{array}$ \\
\hline $\begin{array}{l}\text { Frewen et al., } \\
2013^{6}\end{array}$ & Cross-sectional & $\begin{array}{l}4763 \text { participants } \\
(62 \pm 8 \text { years of age } \\
55 \% \text { female })\end{array}$ & $\begin{array}{l}\text { Two } 5 \text { min supine } \\
\text { resting ECGs }\end{array}$ & $\begin{array}{l}\text { The Montreal Cognitive } \\
\text { Assessment (MOCA) }\end{array}$ & $\begin{array}{l}\text { Reduced HRV was associated } \\
\text { with poorer performance on } \\
\text { the MOCA }\end{array}$ \\
\hline $\begin{array}{l}\text { Zeki Al Hazzouri } \\
\text { et al., } 2014^{7}\end{array}$ & Cross-sectional & $\begin{array}{l}869 \text { Mexican } \\
\text { Americans } \\
(76 \pm 6 \text { years of age } \\
59 \% \text { female })\end{array}$ & $\begin{array}{l}\text { 6-min supine resting } \\
\text { ECG }\end{array}$ & $\begin{array}{l}\text { The Modified MMSE } \\
\text { (3MSE) and the Spanish } \\
\text { and English Verbal } \\
\text { Learning Test (SEVLT) }\end{array}$ & $\begin{array}{l}\text { Reduced HRV was associated } \\
\text { with worse performance on } \\
\text { the } 3 \mathrm{MSE}\end{array}$ \\
\hline $\begin{array}{l}\text { Mahinrad et al., } \\
2016^{8}\end{array}$ & $\begin{array}{l}\text { Cross-sectional } \\
\text { longitudinal }\end{array}$ & $\begin{array}{l}3583 \text { participants } \\
(75 \pm 3 \text { years of age, } \\
53 \% \text { female })\end{array}$ & $\begin{array}{l}\text { 10-s supine resting } \\
\text { ECG }\end{array}$ & $\begin{array}{l}\text { The Stroop test, the } \\
\text { Letter-Digit Coding (LDC) } \\
\text { test and the Picture-Word } \\
\text { Learning Test }\end{array}$ & $\begin{array}{l}\text { Reduced HRV was associated } \\
\text { with poor performance on } \\
\text { the Stroop and LDC tests } \\
\text { in cross-sectional analyses. } \\
\text { Reduced LCD score was also } \\
\text { observed over } 3.2 \text { years of } \\
\text { follow-up }\end{array}$ \\
\hline $\begin{array}{l}\text { Zeki Al Hazzouri } \\
\text { et al., } 2017^{2}\end{array}$ & Prospective & $\begin{array}{l}2118 \text { participants } \\
(45 \pm 4 \text { years of age, } \\
58 \% \text { female })\end{array}$ & $\begin{array}{l}\text { 10-s supine resting } \\
\text { ECG }\end{array}$ & $\begin{array}{l}\text { The Stroop test, the } \\
\text { Digit Symbol Substitution } \\
\text { Test and the Rey Auditory } \\
\text { Verbal Learning Test }\end{array}$ & $\begin{array}{l}\text { Higher HRV at baseline } \\
\text { was associated with better } \\
\text { performance on the Stroop } \\
\text { after } 5 \text { years }\end{array}$ \\
\hline
\end{tabular}

2.30 Abbreviations: CV, cardiovascular; ECG, electrocardiogram; HR, heart rate; HRV, heart rate variability.

between HRV and performance on the Rey Auditory Verbal Learning Test were observed.

The resurrection of interest in HRV and cognition stimu-

2.35 lated by Zeki Al Hazzouri et al. and related literature (Table 1) leads us to consider some interesting directions this work could take in the future. It is inevitable that this research will include studies involving new controls. Among these we recommend statistical adjustment of early-stage and late-

2.40 stage chronic kidney disease, as Brotman et al. ${ }^{12}$ have found that low HRV is associated with early-stage chronic kidney disease and chronic kidney disease-related hospitalization. We also hope to see more longitudinal studies. The study by Zeki Al Hazzouri et al. was prospective, but not longitudinal.

2.45 Does change in HRV over time relate to changes in cognitive performance?

Our curiosity as to nonlinear relations is stimulated by the Zeki Al Hazzouri et al. finding that participants in SDNN quartiles 1 and 4 (the lowest and highest HRV, respectively) 2.50 did not differ in performance on the Stroop Test $(P>0.05)$, although study participants in quartiles 2 and 3 exhibited significantly lower scores than persons in quartile 1 . This appears in Figure 1 of the Zeki Al Hazzouri et al. study as an asymmetrical inverted-U shaped function between SDNN and cognition. Assuming this relation will be repeated, what does it mean and what are its implications for management of HRV?

Zeki Al Hazzouri et al. correctly point out that absence of a significant relationship between the HRV and their test of memory (the Rey Auditory Verbal Learning Test) does not the Rey Auditory Verbal Learning Test does not measure all dimensions of memory. For example, episodic and semantic memory abilities have not been examined in any investigation relating HRV to cognition (Table 1). Semantic memory includes information acquired from personal experience over the lifetime and episodic memory is memory from personal events, e.g., who, what, or when. These 2 types of memories are critical to the recognition of individuals who are on a trajectory to Alzheimer's disease. ${ }^{13}$

Just as is true for memory, EF needs to be indexed by more than a single cognitive test in future studies. The 7 most frequently used test of EF primarily measure mental flexibility, planning, verbal fluency, inhibition of incorrect response (Stroop). ${ }^{14}$ The Stoop Interference Test targets only one of these aspects of the broad construct defined as EF and this is why we prefer a narrower interpretation of the test results obtained using this test.

The word impairment is often used in a comparative sense (i.e., persons with lower scores are described as impaired). In our view, impairment must be defined relative to established clinical criteria. ${ }^{15}$ It is surprising that there have been so few prospective studies relating HRV to impaired performance using defined and established criteria for mild cognitive impairment, all-cause dementia, vascular dementia, and Alzheimer's Disease. We found a single study with findings indicating that low HRV was related to conversion from mild cognitive impairment to vascular Alzheimer's Disease, but not Alzheimer's Disease, although these findings are not yet available in a full-length article. ${ }^{16}$ 
Family and twin studies also indicate a major genetic contribution to resting HRV (heritability estimates between $25 \%$ and $75 \%) .{ }^{17}$ Tools for studying linked gene phenomena in humans are available and it would be interesting to see whether HRV and cognition are related, at least to some degree, as a result of sharing common genetic loci.

While Zeki Al Hazzouri et al. cite work indicating the validity of 10-second electrocardiogram, some data support the argument that recordings should last for at least $30 \mathrm{sec}-$ onds to accurately detect arrhythmias and 60 seconds when heart rate is rapid. ${ }^{18}$ Zeki Al Hazzouri et al. exclude participants with arrhythmias detected within 10 seconds, but it is possible that some cases were undetected because of the short record. This would probably have minimal influence on study results, as the prevalence of steady state and paroxysmal atrial fibrillation is relatively low in the age group studied, but longer electrocardiogram records may become more important in studies with older individuals where the prevalence of atrial fibrillation is 2.3 percent in persons over 40 years of age and rises to 5.9 percent in persons over 65 years. ${ }^{19}$

Of all of the recommendations we make, the use of comprehensive test batteries including multiple domains of cognition and longitudinal studies may be the most difficult to achieve. Achieving these goal places demands on investigator time and increases subject burden and therefore necessitate fewer subjects or, alternatively, longer studies. If we wish to determine which cognitive domains are susceptible to HRV, it is imperative that we meet these goals. They have been achieved in studies of blood pressure and are most assuredly achievable in studies of HRV.

\subsection{DISCLOSURE}

The authors declared no conflict of interest.

\section{REFERENCES}

1. Elias MF, Goodell AL, Dore GA. Hypertension and cognitive functioning: a perspective in historical context. Hypertension 2012; 60:260-268.

2. Zeki Al Hazzouri A, Elfassy T, Carnethon MR, Lloyd-Jones DM, Yaffe K. Heart rate variability and cognitive function in middle-aged adults: the Coronary Artery Risk Development in Young Adults. Am J Hypertens 2017.

3. Kim DH, Lipsitz LA, Ferrucci L, Varadhan R, Guralnik JM, Carlson MC, Fleisher LA, Fried LP, Chaves PH. Association between reduced heart rate variability and cognitive impairment in older disabled women in the community: Women's Health and Aging Study I. J Am Geriatr Soc 2006; 54:1751-1757.

4. Britton A, Singh-Manoux A, Hnatkova K, Malik M, Marmot MG, Shipley $\mathrm{M}$. The association between heart rate variability and cognitive impairment in middle-aged men and women. The Whitehall II cohort study. Neuroepidemiology 2008; 31:115-121.

5. Shah AJ, Su S, Veledar E, Bremner JD, Goldstein FC, Lampert R, Goldberg J, Vaccarino V. Is heart rate variability related to memory performance in middle-aged men? Psychosom Med 2011; 73: 475-482.

6. Frewen J, Finucane C, Savva GM, Boyle G, Coen RF, Kenny RA. Cognitive function is associated with impaired heart rate variability in ageing adults: the Irish longitudinal study on ageing wave one results. Clin Auton Res 2013; 23:313-323.

7. Zeki Al Hazzouri A, Haan MN, Deng Y, Neuhaus J, Yaffe K. Reduced heart rate variability is associated with worse cognitive performance in elderly Mexican Americans. Hypertension. 2014;63:181-187.

8. Mahinrad S, Jukema JW, van Heemst D, Macfarlane PW, Clark EN, de Craen AJ, Sabayan B. 10-Second heart rate variability and cognitive function in old age. Neurology 2016; 86:1120-1127.

9. Richards JE, Casey BJ. Heart rate variability during attention phases in young infants. Psychophysiology 1991; 28:43-53.

10. Mukherjee S, Yadav R, Yung I, Zajdel DP, Oken BS. Sensitivity to mental effort and test-retest reliability of heart rate variability measures in healthy seniors. Clin Neurophysiol 2011; 122:2059-2066.

11. Luft CD, Takase E, Darby D. Heart rate variability and cognitive function: effects of physical effort. Biol Psychol 2009; 82:164-168.

12. Brotman DJ, Bash LD, Qayyum R, Crews D, Whitsel EA, Astor BC, Coresh J. Heart rate variability predicts ESRD and CKD-related hospitalization. J Am Soc Nephrol 2010; 21:1560-1570.

13. Chang HT, Chiu MJ, Hua MS. Early detection of semantic memory changes may help predict the course of Alzheimer's disease. J Alzheimers Dis Parkinsonism 2017;7:333.

14. Faria CA, Alves HVD, Charchat-Fichman The most frequently used tests for assessing executive functions in aging. Dement Neuropsychol 2015; 9:149-155.

15. Elias MF, Robbins MA, Schultz NR Jr, Streeten DH, Elias PK. Clinical significance of cognitive performance by hypertensive patients. Hypertension 1987; 9:192-197.

16. Yoon J, Lee SM, Hong HM. Heart rate variability to differentiate dementia with Lewy bodies from Alzheimer's disease in patients with mild cognitive impairment [abstract]. Mov Disord. 2016; 31(Suppl 2):abstract number 1337.

17. Nolte IM, Munoz ML, Tragante V, et al. Genetic loci association with heart rate variability and their effects on cardiac disease risk. Nat Commun 2017; 8,15805.

18. Shuai W, Wang XX, Hong K, Peng Q, Li JX, Li P, Chen J, Cheng XS, $\mathrm{Su} \mathrm{H}$. Is 10-second electrocardiogram recording enough for accurately estimating heart rate in atrial fibrillation. Int J Cardiol 2016; 215:175-178.

19. Feinberg WM, Blackshear JL, Laupacis A, Kronmal R, Hart RG. Prevalence, age distribution, and gender of patients with atrial fibrillation. Analysis and implications. Arch Intern Med 1995; 155:469-473. 